\title{
Aika hengittää
}

\author{
Eeva-Liisa Viitala
}

\begin{abstract}
Pyristelemmekö kiihkeän muutosvauhdin spiraalikierteessä? Onko ihmisellä tilaa ja aikaa hengittää, ajatella, ymmärtää ja tulla ymmärretyksi, asettua työelämässäkin valoon pyrkivän köynnöksen rytmiin, versoa uutta ja kukoistaa?
\end{abstract}

Helsingin yliopiston kirjaston omalle henkilökunnalleen järjestämässä konferenssissa 14.6.2017 oli tilaisuus saada näkökulma siihen, millaiseksi kirjasto on muotoutumassa painetun sanan jälkeisenä aikana. Päivän aikana kuultujen esitysten mukaan sen tehtävät painottuvat mm. näin:

- kirjasto kannattaa ja tukee tieteellisten tietoaineistojen verkkoavoimuutta ja avointa tiedettä

- etsiytyy tutkijayhteisöihin ja kouluttautuu julkaisupalvelujen tarjoajaksi

- tutkii ja opettaa tieteellisen tiedon mitattavuutta ja vaikuttavuutta antamalla koulutusta tarvittavien välineiden käyttöön

- on mukana yliopiston oppiaineiden opetuksen tukemisessa

- oppimisympäristöjä kehitetään, painettujen julkaisujen hallintaan tarvitaan yhä vähemmän voimavaroja

- dataosaaminen kasvaa ja kansainvälisyys monipuolistuu esimerkiksi tietotaitoa kehittyvään maahan viemällä

Jo olemassa oleva tiivis ja suunnitelmallinen yhteistyö yliopiston tutkimusta ja opetusta tukevien tahojen ja kirjaston sidosryhmien kanssa on myös syytä muistaa vasta vakiintumassa olevista tehtävistä puhuttaessa.

Kirjaston, ja uskoakseni koko informaatioalan muodonmuutos on hyvässä vauhdissa. Helsingin yliopiston kirjaston historia on lähes kahdensadan vuoden mittainen. Yliopistomme kaikista kampusten tiedekirjastoista, tiedekunta- ja laitoskirjastoista muodostettiin vuonna 2010 hal- linnoltaan yhtenäinen erillislaitos, Helsingin yliopiston kirjasto.

Muutosta tapahtuu joka hetki, joka päivä hiukan. Se on niin vähittäistä, ettei sitä yleensä huomaa. Ratkaisevimmat muutosvaiheet on toki huomattu ja koettu aina. Niitä ovat lähinnä kirjastojen yhdistämiset, joiden tahti kiihtyi 1990-luvulta lähtien. Aikaansa seuraavat yliopisto ja kirjastoyhteisöt ovat osa yhteiskuntaa ja toimintaympäristöjään. Ehkäjälleen tulevaisuudessa odottaa kehittyvän teknologian mahdollistama uudenlainen hajautuminen?

Vuoden 2010 jälkeen kirjasto on toiminut jo monessa eri muodossa. Ennen kirjastojen yhdistymistä suunniteltu hallintomalli oli jonkin aikaa toimiva, kunnes räätälöityihin tieteenalapalveluihin perustuvasta kampuskirjastomallista luovuttiin. Käyttöön otettiin toimintokohtainen organisoitumistapa. Koimme jälleen henkilöstö-, toimenkuva- ja tilamuutoksia, työprosessien uudelleen miettimistä... ja muutos on jatkuvaa, jokaista koskettavaa. Toimintaympäristö muuttuu, henkilöstö vähenee, tilat vähenevät - kirjaston toiminnan luonne muuttuu, ehkä enemmän kuin taakse jääneinä vuosisatoina ja vuosikymmeninä koskaan.

Kaikkea ubiikkiyhteiskunnan mahdollistamaa emme osaa vielä kuvitella. Visiot ja tavoitteet lentävät edellämme houkuttelevin sanasiivin. Seuraajat vaihtelevin joukoin kirmaavat perässä, mihinkään kiinnittymättä - mihinkään kiintymättä? Usko hitaaseen kehitykseen ja edistykseen on vaihtunut muutosjoustavuuden, nopean sopeu- 
tumiskyvyn ja jatkuvien yllätysten sietokyvyn painottamiseen. Erona aikaisempaan on se, että kirjastotyössä päivittäisten yllätysten, esimerkiksi vaihtuvien asiakastapahtumien kehyksenä oli jotain pysyvää, käsitys siitä, mikä kirjasto on. Nyt emme vielä tiedä siitä paljon. Eikä entisenlaista kirjastoa instituutiona tule enää olemaan.

Konferenssiesityksiä seuratessa mietin, että Helsingin yliopiston edellisen ja nykyisen strategian visiot ovat nyt konkretiaa. Työtä tehdään kaikkien yliopistolaisten kanssa yhdessä, tutkijoiden, opettajien ja opiskelijoiden parhaaksi ja sitä kautta koko maailman parhaaksi, myös oman maan menestyksen hyväksi. Kirjastossa on asiantuntemusta siitä, miten päästä tietoon, miten arvioida sitä ja miten käyttää ja kehittää tiedon tavoitteluun tarvittavia välineitä.

Kansallisessa ja kansainvälisessä yhteistyössä eri alojen osaajien kanssa hiotaan näkemyksiä ja lisätään taitoa tuottaa keinoja, joilla tietoa yhdistetään ja hyödynnetään. Kirjaston toimintaan kuuluu kaikkeen edellä kuvattuun liittyen myös perinteisesti korkeatasoinen palveluosaaminen. Oma työpaikkaihanteeni, joka on sisältänyt organisaation selkeän suunnan, toiminnan johdonmukaisuuden ja uskottavat tavoitteet, on toteutumassa. Tässä ajassa ja sen mukana kehittyvä Helsingin yliopiston kirjasto on rohkea edelläkävijä.

Kirjastomme henkilöstön osaamisen kehittämiseksi järjestetty konferenssi merkitsi minulle enemmän kuin eri aiheista kuulemiani asiasisältöjä. Tapahtuman muutamien tuntien aikana suuri muutos tuli minulle näkyväksi ja tuntuvaksi samalla tavalla kuin yhteinen seremonia tai riitti alleviivaa, korostaa tai vahvistaa tapahtuneen siihen osallistuville. Päivä oli valon, kuvien ja heijastusten, sanojen ja niiden kaikujen kudos. Tunnen ympärilläni pimennetyn auditorion lämmön, näen hohtavan valkokankaan, puhujat ja puhujien varjot. Kuulen heidän äänensä ja lyhyet keskustelupuheenvuorot. Istun yleisön joukossa hämäräs- sä, rajalla. Tämä voisi olla verkon aineeton, häilyvä, hetki hetkeltä muuttuva maailma, joka ohitse kiitävänä hahmottuu tietokoneen näytölle. Nyt on näin ja huomenna varmaan toisin.

"Vain muutos on pysyvää" ei koske erityisesti meidän aikaamme. Mutta nyt ajan hengityksen rytmi on nopeaa, lähes hengästynyttä. Verkko ja sosiaalinen media on muuttanut myös sen, missä määrin ja miten nopeasti olemme tietoisia aikamme tapahtumista. On mahdollista olla aivan ajan tasalla, hengittää ajan rytmissä ja elää sen sydämen sykkeen tahdissa tai sen lyöntejä ennakoiden. Emme usko enää auktoriteetteja, harhailemme oikean ja väärän tiedon viidakoissa, ihmettelemme, erehdymme, opimme, kysymme ja kyseenalaistamme. Muutos ei etene suorana viivana eteenpäin, vaan spiraalina kierros kierrokselta toistuen, samalla uudistuen. Kaiken taukoamatta tapahtuvan keskelle toivoisin ihmiselle tilaa ja aikaa hengittää, ajatella, ymmärtää ja tulla ymmärretyksi. Siinä suhteessa en tällä hetkellä ole optimistinen.

Tässä ja nyt on kaikki, mitä on. Juuri tässä hetkessä toimimme ja teemme valintoja - tai jätämme tekemättä. Helsingin yliopiston kirjaston vastuulla olevien toimintojen tulevaisuutta emme tarkalleen tiedä, sillä myös se rakentuu koko maailman ja yhteiskuntamme monimutkaisissa kokonaisuuksissa, niiden valintojen tuloksena, joihin eri toimijoilla ja etenkin päätöksentekoon osallistuvilla on mahdollisuudet. Sen tulevaisuuden luomisessa olin kirjastolaisena mukana. Työelämä jälkeen tässä ja nyt - valinnoilleni jää enemmän tilaa - on aika hengittää.

\section{Tietoa kirjoittajasta:}

Eeva-Liisa Viitala tietoasiantuntija

Helsingin yliopiston kirjasto eeva-liisa.viitala@helsinki.fi 